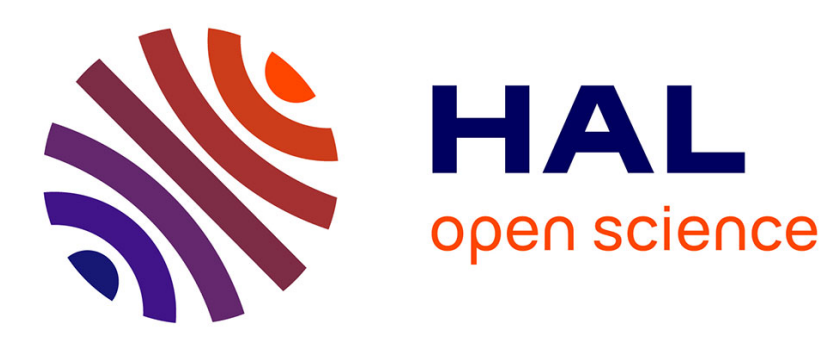

\title{
From Guests and Guides to Collaborators: Negotiating Roles in Design and Biology Collaborations
}

Marguerite Benony, Nolwenn Maudet

\section{To cite this version:}

Marguerite Benony, Nolwenn Maudet. From Guests and Guides to Collaborators: Negotiating Roles in Design and Biology Collaborations. The Design Journal, 2020, 23 (4), pp.557-574. 10.1080/14606925.2020.1762339 . hal-02916775

\section{HAL Id: hal-02916775 \\ https://hal.science/hal-02916775}

Submitted on 17 Aug 2020

HAL is a multi-disciplinary open access archive for the deposit and dissemination of scientific research documents, whether they are published or not. The documents may come from teaching and research institutions in France or abroad, or from public or private research centers.
L'archive ouverte pluridisciplinaire $\mathbf{H A L}$, est destinée au dépôt et à la diffusion de documents scientifiques de niveau recherche, publiés ou non, émanant des établissements d'enseignement et de recherche français ou étrangers, des laboratoires publics ou privés. 


\title{
From Guests and Guides to Collaborators: Negotiating Roles in Design and Biology Collaborations.
}

This is an original manuscript / preprint of an article published in The Design Journal on 13 May 2020, available online: https://doi.org/10.1080/14606925.2020.1762339].

\author{
Marguerite Benony ${ }^{\mathrm{a}}$; Nolwenn Maudet ${ }^{\mathrm{b}}$ \\ ${ }^{\mathrm{a}}$ Université Paris Diderot, Paris, France; ${ }^{\mathrm{b}}$ University of Tokyo, Tokyo, Japan \\ nmaudet@unistra.fr
}

In recent years, the design community has started envisioning biology as a design medium and designers are entering laboratories to pursue designer-biologist collaborations. To ensure that these collaborations lead to rich outcomes, we need to better understand the roles performed by biologists and designers in these collaborations. In seven case studies of collaborations between designers and biologists, we found that strong role dynamics appeared during the collaboration and can be divided into four phases: discovering, defining, developing and delivering. We show how biologists successively act as guides, influencers, supervisors and librarians while designers act as visitors, apprentices, amateurs and lone makers. We found that, despite their interdisciplinarity, projects followed traditional design project structures. While biologists tended to take the lead on project content, designers framed the projects using their methods and processes.

Keywords: collaborative design; design practice; interdisciplinarity; bio-design.

\section{Introduction}

Over the last 50 years, scientists have developed more powerful tools to understand, describe and control living cells. Many biologists, specifically those in the synthetic biology community, have 
come to view living organisms as a medium for production, manipulation, and programming (Collins 2012; Freemont et al. 2012; Fu 2006; Elowitz and Lim 2010). Scientists within this community use language that compares living cells to machines, factories, and computers, introducing engineering and design methods into the scientific practice (Agapakis 2013; Catts and Zurr 2014; Oxman 2016; Ginsberg et al. 2014). Therefore, synthetic biology focuses on 'life by design' (Bensaude Vincent 2015) and proposes, as design does, to make things rather than focusing on understanding existing ones. This perspective has come to influence the design community (Antonelli 2008; Dunne and Raby 2013; Miller 2014) and a growing number of industrial, product and fashion designers started entering biology laboratories to incorporate cells and living systems into their design practice (Myer 2012; Chieza et al. 2018; Camere and Karana 2017). Reflecting on 'Synthetic Aesthetics', a set of pioneering projects that associated designers and biologists, biodesigner Ginsberg explains that 'as synthetic biology attempts to design a new biology, there is an opportunity to reinvent design: if design is to engage in these technologies, it should proactively claim a role in shaping them' (Ginsberg et al. 2014).

As designers entered laboratories, researchers started describing and categorizing the different goals and outputs of natural science and design collaborations (Figure 1). Driver et al. (2011) studied several science and industrial design collaborations and identified three major contributions: to "challenge the research direction and support scientists in demonstrating, communicating and exploring potential future application.' Moultrie (2015) showed how designers can help bridge the 'valley of death' between fundamental research and the commercialization of new products by creating 'design demonstrators'. Rust (2007) argued that 'designers can act as provocateurs in the early stages of interdisciplinary work' as a means to drive scientists to ask ethical questions about their research. Balmer et al. (2016) stated that 'moving the 
societal research upstream, to earlier stages of the research process, imply that societal and environmental implications is part of the scientific development, rather than following it'. For all these reasons, it is important to integrate designers at the early stages of the scientific project in order to address societal concerns.

[Figure 1 near here]

However, in existing accounts of collaborative projects between scientists and designers, both designers and biologists have explained how such collaborations can be challenging. For example, Lee and Agapakis, respectively fashion designer and biologist, discussed the ambiguity of working at the intersection of the two disciplines, showing how designers' concerns don't always align with scientists' ones (Lee 2018). Driver et al. (2011, p.5) conducted a series of interviews 'to gauge scientists' initial perceptions of design as well as to understand their views on how designers might support their research activities'. They reported that 'scientists were generally sceptical about the potential for industrial designers to contribute to early stages of scientific research'.

If we want to ensure that collaborative projects overcome these issues and reliably deliver the different outcomes identified by researchers, we first need a better understanding of how design and biology collaborations currently unfold. However, Peralta and Moultrie (2010) in their literature review on science and design collaboration have noted that 'little work has been carried out in relation to how designers and scientists collaborate in scientific research. [...] For example, in the field of bioscience $[\ldots]$ access to useful information about these initiatives is limited'. Given the unique nature of synthetic biology in the realm of natural sciences, our goal with this paper is to explore and analyse the specificities of design and biology collaboration by looking at how both disciplines engage with each other. 


\section{Related Work}

Design researchers have tried to understand both the differences and similarities between science and design since the origins of the discipline. In their literature review about science and design collaborations, Peralta and Moultrie (2010) summarized the different perspectives on these questions. They show how most authors recognize that design and science are concerned with different objects. Simon (1969) for example expressed that: 'the natural sciences are concerned with how things are [...]. design on the other hand is concerned with how things ought to be'. Krippendorff (2007) argues that science explores the unobservable while design explores the observable. Bonsiepe (2007) similarly suggests that scientists produce 'new knowledge' while designers create 'new experiences' but he also recognizes that designers and scientists both proceed experimentally. Regarding collaboration, we found that while both designers and scientists have strong traditions of collaboration that have been well documented and studied, they differ in that scientists generally collaborate across scientific disciplines while designers collaborate with the many non-designer stakeholders.

In the subsequent paragraphs, we briefly review the literature on how both disciplines respectively collaborate and the roles they traditionally play in the collaboration. Sonnenwald (2007) reviewed the existing literature on collaboration among sciences and found that in natural sciences most publications now result from collaborations and teams are gradually growing bigger. One identified model for successful collaboration is to have well defined and complementary roles (Hara et al. 2003), for example between theoretical and experimental research in physics. However, science collaborations are facing new challenges because they are increasingly ill defined, technically complex, and interdisciplinary' (Leahey 2016). On the design side, designers' interdisciplinary collaborations have mostly been studied in the context of designers and non- 
designers collaborations, especially in the case of participatory design. Researchers have shown how designers can play the role of facilitators. In her study about communication roles that support collaboration during the design process, Sonnenwald (1996) characterize the role played by designers to facilitate a shared understanding across different disciplines as 'interdisciplinary stars' and show how they simplify their language and avoid jargon to do so.

Peralta and Moultrie (2010) argue that interdisciplinary studies provide interesting frameworks for studying design and science collaborations, in particular, they present JohnSteiner's (1998) categorization of interdisciplinary work to show how the forming and performing of roles can profoundly impact the collaborations and the level of integration of disciplines. They show that in the most asymmetrical situation, one discipline can end up being 'tokenized' (Reich et al. 2006), resulting in one-sided collaborations. This situation was for example observed by Dawson (2009) in the context of design and engineering collaborations, when one discipline's role is not well understood by the other. The opposite situation, full collaborations, sees both disciplines establish the research questions and participate in answering them. However, as Peralta and Moultrie showed (2010), despite the wealth of studies about interdisciplinary collaborations involving science or design, we currently lack studies that focus on the relationship between design and biology, and, more specifically, on the specific roles played by designers and biologists in collaborative projects. Chiesa and Ginsberg (2018) also argue that defining new roles for designers alongside biologists would help foster innovation in the emerging field of bio-design. This approach focusing on roles has been used, for example, by Balmer et al. (2015) to understand the multiple and complex patterns of interaction between science and technology (STS) researchers and synthetic biologists. Therefore, in the long term, studying the roles that emerge in current collaborations will help us better prepare designers and biologists who want to engage in such 
collaborations. This paper therefore addresses the following research questions: what roles biologists and designers play in collaborative projects (RQ1), how do they evolve during the projects (RQ2) and how this role distribution affects the materialization of the projects (RQ3)?

\section{Case study and methods}

\section{Case Studies}

[Figure 2 near here]

To answer our research question about the roles of designers and biologists in interdisciplinary collaborations, we selected seven collaborative projects (Figure 2) with designers and biologists in two different universities. In the following paragraphs, we present the case studies, their characteristics and their outcomes to define the scope of our study.

Three collaborative projects took place at Tokyo University in three volunteering biology research labs over the course of eight weeks. Researchers in the first participating lab work on living and electronic sensors to detect environmental chemicals. The second lab is dedicated to regenerative medicine and the culture of living tissues. The third is a neuroscience lab experimenting on lab grown neuron bundles.

Participants included five industrial designers recently graduated from the Royal College of Art (London, UK), three master students from the University of Tokyo and three biology professors who supervised the projects. One designer had trained as a scientist before enrolling at the design school. Over the course of the collaboration, the biologists and designers broke into three teams of two to four students. At the end of the collaboration, all three projects have been exhibited in the university as well as at the National Art Center, Tokyo. One project directly led to 
a new research direction and a second project led to a new collaborative project by the same team, this time aiming at developing a product based on the research developed by the laboratory. Both of these projects are being developed at the time of writing.

Five collaborative projects took place at the CRI in Paris in one volunteering research laboratory focusing on research in synthetic biology, over the course of twelve weeks. The cohort included eleven masters level product design students from Ecole Boulle, five masters level biology students from Paris Diderot and Descartes Universities, and two Post-Doctoral researchers in synthetic biology who supervised the projects. None of the participants had worked across disciplines, but one biology student had a bachelor's degree in art. Over the course of the collaboration, the biology and design students broke into five teams of three-to-five students. As part of the program, the students were introduced to fundamental concepts in biology and exposed to hands-on laboratory work. At the end of the collaboration, all the projects were exhibited in museums in Paris and New York as part of the Biodesign Challenge program. One of the projects is being developed as a research project in the CRI laboratory at the time of writing and two other projects have been exhibited at several science and design fairs.

In all of the projects, no explicit methods or tools were imposed on the participants. To see how the different collaborators were naturally developing their own methods, they were free to arrange the collaboration in the way that suited them the best. Teams also had to collaboratively come up with their own brief from the research. While no specific outcomes were required, participants knew that their projects would be displayed in exhibitions.

[Figure 3 near here] 


\section{Methodology}

The purpose of the study is to understand how collaborations unfold in multi-disciplinary teams of designers and biologists. In an initial phase, one author acted as a participant observer in the projects conducted in Paris. These initial observations revealed that the roles were not fixed but instead constantly evolved throughout the process. These initial insights guided the creation of the semi-structured interview process that was then carried out with all the participants. We conducted 21 post-hoc semi-structured interviews (Breakwell 2006; Denzin 1994) with 5 master's-level biology students, 12 designers as well as the 4 mentors (biology professors). 10 individual interviews were performed in Tokyo and 8 interviews were performed in Paris, individually with biologists and with designers' teams for each project. Each interview lasted from 1-1.5 hours. Specifically, we first asked participants about how the collaboration unfolded, the roles and the concrete activities that they performed at the different moments of the project, their strategies for collaboration, and the frictions that arose during the collaborative process. The authors audiorecorded the interviews, took handwritten notes, and later transcribed the interviews in adherence to the transcribing methods described by Saldana (2015). Each participant has been attributed a code according to their profession, their institution and their project (see Figure 3).

We analysed the interviews using the approach to thematic analysis developed by Clarke and Braun (2014). We identified the roles in an inductive manner and we regularly met to discuss the data, the coding and our interpretations, to ensure that they were coherent, comprehensive and reflective of the actual data in both the Paris and Tokyo projects. We grouped codes into categories and went back again to the interviews to consistently apply these emerging categories (see Appendix A). 


\section{Dynamics of designers and biologists' roles in the project}

We observed the emergence of strong role dynamics between designers and biologists during their collaboration. In our analysis we found that all the projects followed a similar path that could be divided into four distinct phases: discovering, defining, developing, delivering, during which designers and biologists played very distinct roles. We should note here that the different phases and roles were never formally defined within the teams but our analysis revealed that they consistently emerged throughout the course of the projects in all the teams. We present them below in chronological order and we detail the specific roles performed during each phase by both designers and biologists.

\section{Discovering}

\section{Designers as guests}

Designers started the project with their own desires and interests, mostly materials or thematic, as external elements that they wanted to confront the biological matter. They initially perceived the laboratory as a playground, a place to explore, especially due to its 'exotic' tools and a strict 'scientific method' $\left(\mathrm{P}_{2} \mathrm{Des}_{\mathrm{b}}\right)$. As $\mathrm{P}_{2}$ Desb explained, they assumed that working with biologists would involve creating and manipulating biological material. For example, $\mathrm{P}_{1} \mathrm{Des}_{\mathrm{b}}$ came with the idea of working with ceramics and DNA while $\mathrm{P}_{4} \mathrm{Des}_{\mathrm{a}}$ already knew that he 'wanted to design a clock with an organic display'. In contrast, biologists arrived with no preconceived ideas about the project. Even more, at first $\mathrm{P}_{1}$ Bio didn't know 'what [he/she] could bring to the project and didn't understand [his/her] role in such competition'. 


\section{Biologist as guides}

Biologists found their first active role in the project as tutors to guide designers in their discovery of a biology laboratory. At first, biologists did not know what or how they should present their research to an audience of designers. Some biologists, like $\mathrm{T}_{1} \mathrm{Bio}_{\mathrm{b}}$, had the impression that 'designers would not be interested in their daily research activities'. $\mathrm{T}_{1} \mathrm{Biob}_{\mathrm{b}}$ and $\mathrm{T}_{2,3} \mathrm{Bio}$ both explained how they tried to focus on the visible and tangible aspect of their research, especially the materials and visuals that they use. For example, $\mathrm{T}_{1} \mathrm{Biob}$ tried to describe the material qualities of neurons to designers: 'I also showed that we can stretch it if you attach it to a small pin'. Nevertheless, biologists had an instinctive sense of which part of their research would be interesting starting points: for project $P_{1}$, the mentors $M_{1}$ and $M_{2}$ encouraged the designers to focus on a DNA detection process even if designers 'didn't see at first the point of working on it' $\left(\mathrm{P}_{1} \operatorname{Des}_{\mathrm{b}}\right)$. The designers later admitted that "she was right to show us that it was the right subject, the right direction'. $\mathrm{T}_{2,3} \mathrm{Bio}$ demonstrated the different colour lenses that she can use to observe her samples, thinking that designers could find this colour change interesting. $\mathrm{T}_{1}$ Biob also 'focused more on how to do the experiment', rather than her current research on proteins that regulate the morphology in the brain because she thought that 'it's not very interesting for them'. In a similar manner, at the beginning of the $T_{1}$ project, designers were initially interested in the genetic aspect of professor's $\mathrm{T}_{1} \mathrm{Bii}_{\mathrm{a}}$ research, but he thought that it would be 'too difficult for designers to edit genes by themselves in the laboratory' so he argued against it. 


\section{Defining}

\section{Biologists as influencers}

The way biologists presented information to designers had a very strong impact on the generated concepts. For example, in the case of $\mathrm{T}_{3}$, designers reified the metaphor that professor $\mathrm{T}_{3}$ Bio used to describe her research: 'We already had the idea at the microscopic scale, they did it at a macro scale'. In the case of $\mathrm{P}_{1}$ project, $\mathrm{M}_{2}$ explained that while they were using a sophisticated machine to duplicate DNA '[they] could as well be heating with a candle'. As a result, designers took this statement literally and developed their project based on a tealight candle. $\mathrm{P}_{1}$ Desb explained that they would not have arrived at this idea on their own because it could have appeared as a dilettantism, as if they did not respect the science. Beyond the discourse, biologists' concrete practices and gestures also inspired designers: $\mathrm{P}_{1} \mathrm{Des}_{\mathrm{a}}$ explained that the DIY approach of her project was inspired by the biology student $\mathrm{M}_{2}$ who 'hacks his own tools to do his project'. The laboratory and its numerous unknown artefacts were also a source of inspiration for designers who could understand the research from a different perspective, by inquiring about when and how they were used and if they were disposed after use or not.

\section{Designers as 'elastic minds' (Antonelli 2008)}

One of the main strategies used by designers to ideate from scientific research was to extrapolate a specific research finding. In the case of project $T_{2}$, professor $T_{2}$ Bio managed to create a biohybrid device to detect a molecule from sweat. Designers posited that this research finding could be extended and applied to sense every molecule. In project $T_{1}$, professor $T_{1} B i_{a}$ was also very surprised at first when designers came up with the idea of using the armpit to incubate neuron but he realized that 'they came up with the armpit, because we said neurons are fragile and need a 
good environment at $37^{\circ} \mathrm{c}$ with nutriments'. In $\mathrm{P}_{1}$, students also chose to extend the purpose of a technology that was already created in the laboratory. Originally, biologists had devised a technique to test food for Genetically Modified Organisms (GMOs). $\mathrm{P}_{1}$ Bio explained that 'it was only usable in a specific case, when the food is based on corn or soy'. Adding, 'the challenge led us to think about turning it into a more universal project that can be used by anybody [...].'

\section{Biologists as 'bridges between ideas and reality'}

However, we observed that it was difficult for biologists to engage with this type of ideation, because they know the current limitations of their research and how hard reproducing experiments can be. In the Tokyo lab, when designers proposed to work on an artificial brain made of thousands of the organoids created by professor $\mathrm{T}_{1} \mathrm{Bio}_{\mathrm{a}}$, the latter felt that it was too far from his research: 'We already have issues with connecting two together for now'. Similarly, $\mathrm{T}_{1}$ Biob explained her difficulties to propose design ideas during the brainstorming sessions with designers because 'researcher on the field are really restricted by the difficulty of the experiment'. In the beginning, biologists were sometimes at a loss for how to respond to designers when confronted with designers' ideas that seemed currently impossible on a scientific level. However, as $\mathrm{T}_{1} \mathrm{Biob}_{b}$ came to reflect during the interview, biologists gradually found their place by becoming 'the bridge between the reality and the idea'. She explained how she established her role in setting up a scientific roadmap with the different 'obstacles to overcome' in order to make the idea a reality: 'Thinking about the process to make the thing and not trying to deny it'. 


\section{Developing}

\section{Practice: designers as apprentice}

As first ideas were emerging, designers in all the groups wanted to experiment, to get their hands dirty in the lab, even if they did not directly work with the suitable material. For example, $\mathrm{P}_{2}$ group 'did a lot of tests, but not using the real data' $\left(\mathrm{P}_{2} \mathrm{Des}_{\mathrm{a}}\right) . \mathrm{P}_{3}$ 's designers 'experimented with bacteria but it wasn't the one that produces indigo' $\left(\mathrm{P}_{3} \mathrm{Des}_{\mathrm{a}}\right)$ while in the $\mathrm{T}_{1}$ project, $\mathrm{T}_{1} \mathrm{Des}_{\mathrm{a}}$ explained that, in the first phase, they broadened the ideas and did not research the actual academic content: 'We didn't set any restrictions so that we could come up with any idea'. After the first autonomous experimentations, as all attempts of growing biological matter were failing, designers realized that they had to learn the rigor of scientific experimentation from the biologists 'to be able to really start the project' $\left(\mathrm{P}_{3} \operatorname{Des}_{\mathrm{c}}\right)$.

\section{Practice: biologists as supervisors}

In this phase as well, biologists came to the rescue: they started to lead the experimental part and designers took on the role of scientific assistants. They gradually learned the experimental gestures through observation and imitation. As $\mathrm{P}_{4} \mathrm{Des}_{b}$ explains, ' ${ }_{4}$ Bio was doing the experiments, but we tried to understand, we were observing over her shoulder'. Designers were 'taking notes' and also 'took a lot of pictures to be able to understand and reproduce the same thing' by themselves $\left(\mathrm{P}_{3} \operatorname{Des}_{\mathrm{c}}\right)$. Another strategy explained by $\mathrm{P}_{3}$ Desb was to 'always manage to be in the lab at the same time as $\mathrm{P}_{3} \mathrm{Bio}$ when she was working on the project, so we could watch her and learn'. Repetition was also crucial for designers to learn how a scientific protocol is carried out through microvariations until 'it had become very familiar.' $\left(\mathrm{P}_{3} \mathrm{Des}_{\mathrm{a}}\right)$. After a few sessions 'it was like holding a paintbrush' for her. 


\section{Theory: designers as amateurs}

Alongside their apprenticeship of experimental biology, designers also looked for more theoretical scientific knowledge to enrich the projects. $\mathrm{P}_{2}$ Des $_{\mathrm{a}}$ explained that they first turned to second hand sources, looking at popular science journals and visiting local Science Museums. However, $\mathrm{P}_{2} \mathrm{Bio}$ was sending designers scientific articles and diagrams because 'according to him, our websites were not scientific enough' $\left(\mathrm{P}_{2} \mathrm{Des}_{a}\right)$. The original asymmetry in knowledge was reinforced by the fact that only biologists knew where to find and how to read original sources. Indeed, journal articles are written for scientists in the field and can be extremely hard to understand for outsiders. Biologists needed to act as mediators and provide a translation from scientific content into information usable by designers. As $\mathrm{P}_{4}$ Des $_{a}$ explained, 'When $\mathrm{P}_{4}$ Bio was finding a website with interesting information, she would show it to us, but the information did not come across to us, whereas she would understand it right away'. However, even if designers were looking for information, they also thought that 'going too deep into scientific details was slowing the project sometimes' $\left(\mathrm{P}_{2} \mathrm{Des}_{\mathrm{a}}\right)$. According to $\mathrm{P}_{2} \mathrm{Des}_{\mathrm{a}}$, 'there is a paradox between fully understanding something and knowing what is necessary for design'. At the end of the project, after having spent several months growing bacteria, designers $\mathrm{P}_{3} \operatorname{Des}_{\mathrm{c}}$ admitted that they 'still don't know how bacteria worked but we didn't need to know this for the project' and $\mathrm{P}_{2} \mathrm{Des}_{\mathrm{b}}$ had reached a deep level of understanding of the functioning of DNA 'but nothing in what's around it'.

\section{Theory: biologists as librarian}

Biologists felt that it was their role to teach theoretical biology to designers, in order for them to understand the experiments they were conducting. Biologists used diverse strategies to transmit their knowledge, from 'explaining to a 5 year-old' $\left(\mathrm{T}_{1} \mathrm{Bio}_{\mathrm{b}}\right)$ to using drawings and diagrams. Biologists also became knowledge referents even though they themselves did not always have the 
knowledge. Designers expected scientists to do the 'validation step with [their] knowledge' $\left(\mathrm{P}_{4} \mathrm{Des}_{\mathrm{a}}\right)$ by answering their questions. Thus, biologists were being used to find resources outside of the laboratory to develop the project. Biologists had access to a network of colleagues to whom they could directly 'send the question via email' $\left(\mathrm{P}_{4} \mathrm{Des}_{\mathrm{a}}\right)$ and who could refer to the relevant sources to solve problems or confirm hypothesis. For designers, this role distribution felt natural: 'It was simpler for [biologists] to contact researchers. It's also a matter of scientific language.' $\left(\mathrm{P}_{4} \mathrm{Des}_{\mathrm{b}}\right)$. Interestingly, while designers gradually managed to learn and master the art of experimentation, they never managed to become autonomous on the theoretical side of the project.

\section{Delivering}

\section{Designers as lone makers and biologists' exclusion}

Despite the original desire to set up a perfect environment for a hybrid project between design and biology, all design students wanted to work first on the biology part, and as they came to master it, they wanted to shift to the design part. Biology had become the means to an end, or as $\mathrm{P}_{3} \mathrm{Des}_{\mathrm{a}}$ puts it: 'the scientific tool to create'. As a result, biologists were mostly evicted from this phase. This eviction of biologists during the design phase of the project was also justified by designers as a matter of planning and timing, as they had 'only little time to do the project' $\left(\mathrm{P}_{4} \mathrm{Des}_{\mathrm{a}}\right)$, and were 'under pressure to make the project happen' ( $\left.\mathrm{T}_{2} \mathrm{Des}\right) . \mathrm{P}_{2} \mathrm{Bio}_{\mathrm{a}}$ explained that 'designers conducted the fabrication process while $\mathrm{P}_{2} \mathrm{Bio}$ was there as a fact checker, or manual help, but he was not involved in the design process'. In that sense, biologists became tokens of truth. On the other side, biologists were looking for interactions that designers were not spontaneously offering them. They had suggestions on the design and also had their own opinions but they had to use strategies to have their voice heard by designers, such as 'whispering new ideas' $\left(\mathrm{P}_{2} \mathrm{Des} b\right)$. At the end of the 
project, some designers expressed regrets about the fact that they had not involved biologists in the design process and that 'If we had to do it again, we would integrate her more into the design of the object' $\left(\mathrm{P}_{4} \operatorname{Des}_{\mathrm{a}}\right)$.

Designers wanted to visually demonstrate their concept: 'doing something that give the impression that it's working and that will show people the potentialities' $\left(\mathrm{P}_{4} \mathrm{Des}_{a}\right)$ while scientists wanted to develop functional prototypes. The difficulty to produce functional prototypes with biological matter as a design material had a strong influence on the resulting design. In $\mathrm{T}_{2}$ project for example, they represented the function of the object literally: 'every dot represents a specific chemical, there are 50 of them on a sheet of $1 \mathrm{~cm}$ ' $\left(\mathrm{T}_{2} \mathrm{Des}\right)$. Because they could not produce a functional prototype, they needed to convey the function through the object shape and visual detail. They therefore used biology as an aesthetic reference to design the object. In $T_{3}$ project as well, designers decided to print images of blood vessels to illustrate what the sheets could look like and added jelly on top of it to make it 'looks more like bio' $\left(\mathrm{T}_{2} \mathrm{Bio}\right)$.

\section{Designers and biologists as collaborators}

The projects had a short time span from a biology perspective but all had to produce outputs that would be displayed at exhibitions as well as in the Biodesign Challenge for the projects developed in Paris. A strong emphasis was therefore put on presenting and communicating the research behind the objects. The very end of the project and the finalization phase was the only moment when 'roles got completely mixed and there were no designers and no scientists anymore.' $\left(\mathrm{P}_{2} \mathrm{Bio}\right)$. For scientists, this mission was seen as a natural continuation of their teaching mission during the whole project. They crafted the stories that back-up the projects and the design choices at the end. Science was thus used for its authority and as a justification mechanism for design and allowed teams to 'build the story while building the product' $\left(\mathrm{T}_{2,3} \mathrm{Des}\right)$. 


\section{Discussion}

We observed the emergence of strong role dynamics between designers and biologists during their collaboration. In our analysis we found that all the projects followed a similar structured during which designers and biologists played very distinct roles. In the initial discovery phase, designers acted as guests while biologists were acting as guides in the laboratory. In the defining phase, biologists became influencers and tried to bridge the gap between designers' ideas and reality. In the developing phase, designers acted as apprentices and amateurs while biologists acted as supervisors and librarians. Finally, in the delivering phase, while biologists were evicted from the design process that was carried out by designers, both disciplines collaborated on equal terms for crafting the reasoning that supported the projects.

In this study, we identified a novel type of interdisciplinary collaboration dynamic that differs from the ones observed by John-Steiner (1998). Our analysis revealed the strongly asymmetrical collaboration roles performed by designers and biologists during the projects. More than collaborations on equal terms, roles were instead strongly enforced and the two disciplines were mobilized in very different ways in the project. This asymmetry cannot accurately be described as tokenism (Reich et al. 2006) nor can it be seen as simply one sided (Dawson 2009). It is asymmetrical in that designers were leading on the process while biologists were leading on the content. Specifically, in the projects we analysed, we observed how designers take the lead on organizing the project time and activities. This can also be seen in the fact that the four phases of the projects we identified echo traditional divergence-convergence phases in the design process as described by Cross (2000). If those phases appear familiar to designers, we found that they also closely match the four key stages of scientific collaboration defined by Sonnenwald (2007) in her 
literature review: 'foundation, formulation, sustainment, and conclusion'. This might explain why both designers and biologists, in all the projects we studied, managed to organize the collaboration implicitly and did not question it during the interviews.

Despite having designers leading on the process during the collaboration, our analysis also revealed the critical role played by biologists in almost all the steps. As we have seen in our analysis, because designers first get access to the biological matter through biologists' eyes, hands and knowledge, their vision and their possibilities are enabled and shaped by biologists. We also observed how biologists were constantly redefining their role and adapted their practices to support the projects, while designers mostly performed traditional design activities. In that sense, biologists played the design game: they adapted to designers' ideas and tried to make them viable, taking on the role of bridge between designers' ideas and the biological practices and knowledge needed to achieve the projects. Biologists also had a reflexive approach on their work and their tools that helped designers question and appropriate biology. Biologists were also gatekeepers: designers were always seeking confirmation and validation and relied on biologists' ability to interpret their ideas and adapt them to the scientific reality and constraints. Callon (1984) observed how scientists find their place and mobilize different partners through a process called 'interessement' in which they translate the concerns of the non-scientists to their own terms. In the collaborations analysed here, we observed a similar movement, but, this time, performed by designers as they made biologists their allies in the development of the project. In the later phases especially, we observed how designers translated the biologists world into their own, by appropriating their aesthetic for example. Thus, designers treated biology as a material to design, more than a scientific field or discipline in its own right. 


\section{Conclusion}

Through seven use cases of design and biology collaborations in two different universities, we explored the roles played by both disciplines in the collaboration, how they evolved (RQ1) and how they impacted the projects (RQ2). Informed by participant observation, our 21 post-hoc interviews with both designers and biologists revealed strong asymmetrical collaboration patterns: designers and scientists took on complementary roles that strongly shaped the projects. Biologists performed the roles of guides, influencers, bridges between ideas and reality, supervisors and librarians. Designers acted as guests, apprentices, amateurs and lone makers. It is only at the end of the 'delivering' phase that both designers and biologists became peers. We also found that the projects followed a mostly traditional design project structure despite their interdisciplinarity and access to laboratory equipment. Biologists led on the content of the projects, but designers framed the projects based on their methods and processes. Designers mostly developed an instrumental relationship to biology, eagerly adopting its materiality but seldom including biologists in the design process, until the final stage of the project. Finally, we looked at how this roles' distribution affected the materialization of the projects (RQ3): We show biologists' decisive influence on early project ideas and how, in later phases, we show how designers treated biology as a material to design and as an aesthetic, more than a scientific field or discipline in its own right.

This study also has some limitations we would like to acknowledge. In such collaborations, differences of seniority and expertise can strongly influence the collaboration patterns; we need more studies to understand how different expertise level can influence collaborations. While the use case selected in this study were diverse in terms of topics explored by the teams, they all happened in a university context and were relatively short projects when compared with traditional 
biology projects' timeframe (Ginsberg et al. 2014) that usually last for several years. They were, however, closer to traditional design project timeframes. Collaborations happening in the long run may lead to different roles and collaboration patterns that should also be studied.

As the interest in bio-design is growing and more and more design and biology collaborations are being set up, this research shows that we need to carefully consider the environment of bio-design projects to fully explore the potential of working with biologists. Revealing and making explicit the roles that can spontaneously emerge in the collaboration can help both designers and biologists to reflect on their roles in the collaboration. Taking advantage of their outsider position on scientific knowledge, designers could look at it differently and eventually 're-conceive both the object(s) of research and the relations between research subjects and objects' (Barry et al. 2008). Using this work, we plan to develop tools and methods that encourage designers and biologists to explore other patterns of collaboration.

\section{Acknowledgments:}

The two authors share first authorship. This work was supported by University Paris Diderot; Ecole Boulle; SCIRE Association as well as JSPS FY2017 Postdoctoral Fellowship.

The authors would like to thank Dan Grushkin for his helpful comments and English revisions as well as all the biologists and designers who participated in this project.

\section{Disclosure statement}

No potential conflict of interest was reported by the author. 


\section{References}

Agapakis, Christina M. 2014. "Designing Synthetic Biology.” ACS Synthetic Biology 3 (3): 12128._doi: https://doi.org/10.1021/sb4001068.

Antonelli, Paola, and Hugh Aldersey-Williams. 2008. "Design and the Elastic Mind." New York: The Museum of Modern Art.

Balmer, Andrew S., Jane Calvert, Claire Marris, Susan Molyneux-Hodgson, Emma Frow, Matthew Kearnes, Kate Bulpin, Pablo Schyfter, Adrian MacKenzie, and Paul Martin. 2015. 'Taking Roles in Interdisciplinary Collaborations: Reflections on Working in Post-ELSI Spaces in the UK Synthetic Biology Community’. Science \& Technology Studies.

Barry, Andrew, Georgina Born, and Gisa Weszkalnys."Logics of Interdisciplinarity.” Economy and Society 37 (1): 20-49.

Bensaude Vincent, Bernadette. 2013. "Ethical Perspectives on Synthetic Biology”. In Biological Theory, 68-375. Cambridge: Massachusetts Institute of Technology Press.

Bensaude Vincent, Bernadette. 2015. "Life by design: Philosophical perspectives on synthetic biology". BIO web of conferences 4, EDP Sciences.

Bonsiepe, Gui. 2007. “The Uneasy Relationship between Design and Design Research.” In Design Research Now: Essays and Selected Projects, edited by Ralf Michel, 25-39. Basel: Birkhäuser Basel. https://doi.org/10.1007/978-3-7643-8472-2_2.

Breakwell, Glynis M. 2006. "Interviewing methods”. In Research Methods in Psychology, edited by John Smith, 232-253. London: Sage Publication.

Callon, Michel. 1984. "Some Elements of a Sociology of Translation: Domestication of the Scallops and the Fishermen of St Brieuc Bay." The Sociological Review 32 (1): 196-233. doi: https://doi.org/10.1111/j.1467-954X.1984.tb00113.x. 
Camere, Serena, and Elvin Karana. 2017. “Growing materials for product design” Paper presented at the EKSIG 2017: Alive. Active. Adaptive conference, Delft, June.

Carlson, Robert. 2010. "Biology is technologys: the promise, peril and new business of engineering life". Harvard University Press, Cambridge,

MA

Catts, Oron, and Ionat Zurr. 2014. "Growing for Different Ends." The International Journal of Biochemistry \& Cell Biology $56 \quad$ (November): $20-29 . \quad$ doi: https://doi.org/10.1016/j.biocel.2014.09.025.

Chieza, Natsai, and Alexandra Daisy Ginsberg. 2018. "Editorial: Other Biological Futures," Journal of Design and Science 4 (September). doi: https://doi.org/10.21428/566868b5.

Clarke, Victoria, and Virginia Braun. 2014. "Thematic Analysis.” In Encyclopedia of Quality of Life and Well-Being Research, edited by Alex C. Michalos, 6626-28. Dordrecht: Springer Netherlands. doi: https://doi.org/10.1007/978-94-007-0753-5_3470.

Collins, James. 2012. "Synthetic biology: bits and pieces come to life". Nature 483, S8-S10. doi: https://doi.org/10.1038/483S8a

Cross, Nigel. 2000. Engineering Design Methods: Strategies for Product Design. John Wiley \& Sons Inc.

Davis, Joe. 2006. "Art and genetics". eLS Published online September 15. http://dx.doi.org/10.1002/9780470015902. A0005868

Dawson, Emily. 2009. “On Constructing Collaborations between Engineers, Designers and Publics.” In Material Beliefs, edited by Kerridge, Tobie, 132-136. London: Goldsmiths University.

Denzin, Norman .K., and Yvonna S. Lincoln. 1994. Handbook of Qualitative Research. Thousand Oaks, CA, US: Sage publications. 
Driver, Alex, Carlos Peralta, and James Moultrie. 2011. "Exploring How Industrial Designers Can Contribute to Scientific Research.” International Journal of Design 5 (1):17-28.

Dunne, Antony, and Fiona Raby. 2013. Speculative Everything. Design, Fiction and Social Dreaming. Cambridge, MA: The MIT Press.

Elowitz, Michael, and Wendell A. Lim. 2010. "Build Life to Understand It." Nature 468 (7326): 889-90. https://doi.org/10.1038/468889a.

Fu, Pengcheng. 2006. “A Perspective of Synthetic Biology: Assembling Building Blocks for Novel Functions." Biotechnology Journal 1 (6): 690-99. doi: https://doi.org/10.1002/biot.200600019. Freemont, Paul, and Richard Kitney. 2012. Synthetic Biology: A Primer. London: Imperial College Press.

Ginsberg, Alexandra Daisy, Jane Calvert, Pablo Schyfter, Alistair Elfick, and Drew Endy. 2014. Synthetic Aesthetics: Investigating Synthetic Biology's Designs on Nature. Cambridge: MIT Press. Hara, Noriko, Paul Solomon, Seung-Lye Kim, and Diane H. Sonnenwald. 2003. “An Emerging View of Scientific Collaboration: Scientists' Perspectives on Collaboration and Factors That Impact Collaboration." Journal of the American Society for Information Science and Technology 54 (10): 952-65. https://doi.org/10.1002/asi.10291.

John-Steiner, Vera. 1998. Creativity and Collaboration, a sociocultural approach. Paper presented at the Annual Research Lecture, Office of Research Services, University of New Mexico, Albuquerque, NM.

Krippendorff, Klaus. 2007. "Design Research, an Oxymoron?". In Design research now: Essays and selected projects, edited by R. Michel, 67-80. Basel: Now Publisher Birkhäuser. 
Leahey, Erin. 2016. "From Sole Investigator to Team Scientist: Trends in the Practice and Study of Research Collaboration.” Annual Review of Sociology 42 (1): 81-100. https://doi.org/10.1146/annurev-soc-081715-074219.

Lee, Suzanne, and Christina Agapakis. 2018. "Design With Science,". Journal of Design and Science 4 (1) September. https://jods.mitpress.mit.edu/pub/issue4-agapakis-lee.

Miller, Arthur I. 2014. Colliding Worlds: How Cutting-Edge Science Is Redefining Contemporary Art. London: W. W. Norton \& Company.

Moultrie, James. 2015. "Understanding and classifying the role of design demonstrators in $\begin{array}{lllll}\text { scientific } & \text { exploration". } & \text { Technovation } & 43-44, & 1-16 .\end{array}$ https://doi.org/10.1016/j.technovation.2015.05.002

Myer, William. 2012. Biodesign, Nature, Science, Creativity. High Holborn: Thames \& Hudson. Oxman, Neri. 2016. "Age of entanglement". Journal of Design and Science (1).

Peralta, C, and James Moultrie. 2010 "Collaboration between designers and scientists in the context of scientific research: a literature review" in DS 60: Proceedings of DESIGN 2010, 16431652. Dubrovnik : the 11th International Design Conference.

Reich, Stephanie M. and Jennifer Reich. 2006. "Cultural Competence in Interdisciplinary Collaborations: A Method for Respecting Diversity in Research Partnerships". American Journal of Community Psychology 38: 1-7. doi:10.1007/s10464-006-9064-1

Rust, Chris. 2007. "Unstated contributions: how artistic inquiry can inform inter-disciplinary research”. Design Issues 20(4), 76-85. doi: https://doi.org/10.1162/0747936042311959

Saldana, Johnny. 2015. The Coding Manual for Qualitative Researchers. Thousand Oaks: Sage Publication Ltd.

Simon, Herbert A. 1996. The sciences of the artificial. Cambridge: MIT press. 
Sonnenwald, Diane H. 1996. "Communication Roles That Support Collaboration during the Design Process." Design Studies 17 (3): 277-301. https://doi.org/10.1016/0142-694X(96)00002$\underline{6}$.

Sonnenwald, Diane H. 2007. "Scientific Collaboration." Annual Review of Information Science and Technology 41 (1): 643-81. https://doi.org/10.1002/aris.2007.1440410121.

\section{Biographical note}

Marguerite Benony is a third year PhD student at University Paris Diderot. She was trained as a designer from Ecole Boulle and ENS Cachan. Her PhD project deals with designing the future of research and of laboratories in life sciences.

Nolwenn Maudet is an interaction designer and a design researcher at the Université de Strasbourg. She obtained her PhD in Human-Computer Interaction from the University of Paris-Saclay. As a design researcher, she studies how designers work with their digital tools and with other communities of practice.

\section{Address for correspondence}

Nolwenn Maudet, University of Tokyo, Tokyo, Japan

Email:nmaudet@unistra.fr 


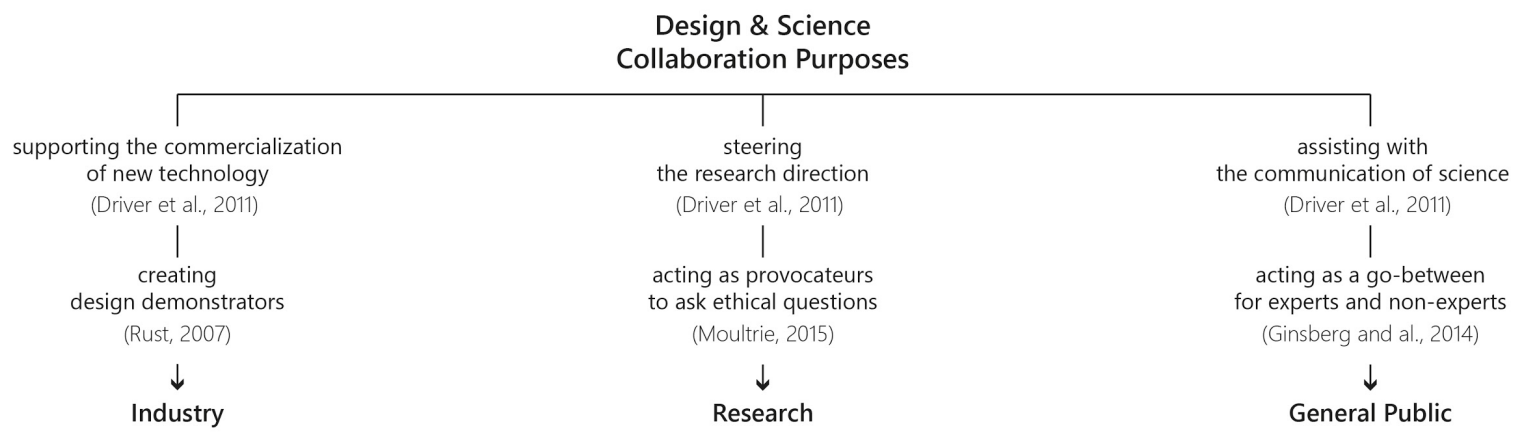

Figure 1. Design and science collaboration purposes, as identified by previous research, can be classified in three categories: projects for the industry, for research and for the general public. 


\section{Paris}

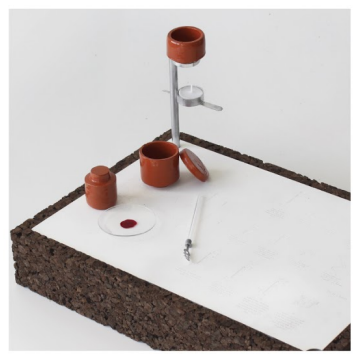

Minima, the elementary biology lab $\mathrm{P}_{1}$

\section{Tokyo}

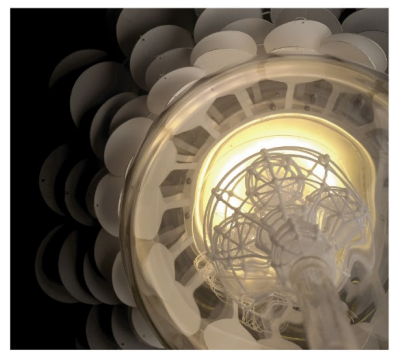

Aura

$\mathrm{T}_{1}$

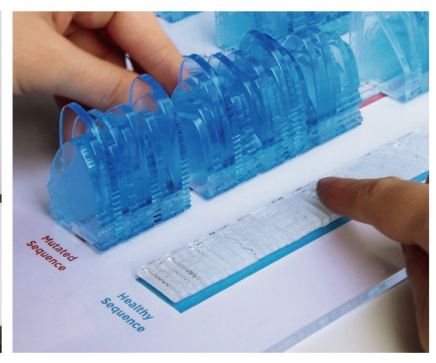

Tactile Micro Landscape $\mathrm{P}_{2}$

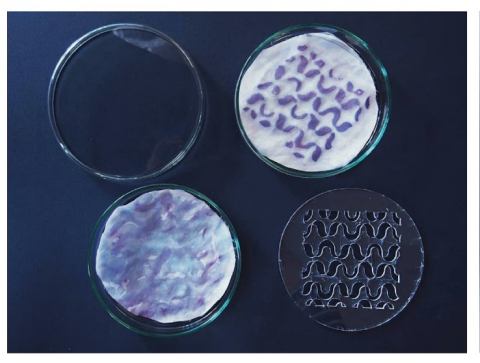

IndiCo

$\mathrm{P}_{3}$

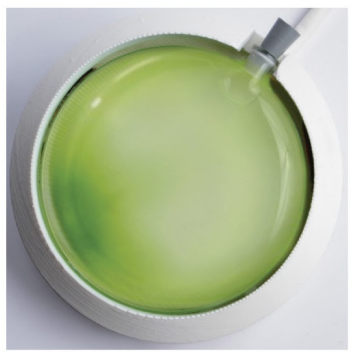

Bio-Clock

$\mathrm{P}_{4}$

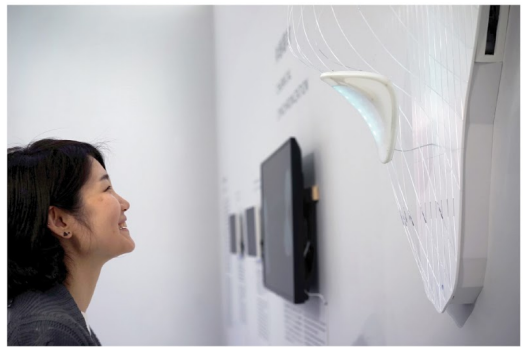

Chemical Synchronisation $\mathrm{T}_{2}$

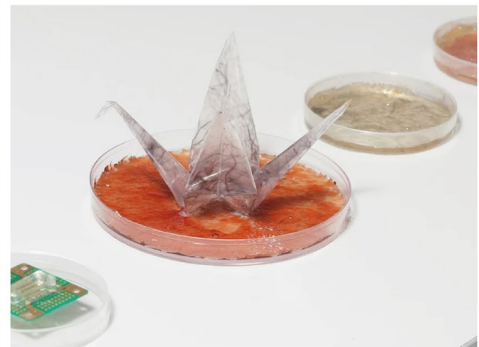

BIOrigami

$\mathrm{T}_{3}$

Figure 2. Resulting artifacts from the seven collaborative projects studied. 


\begin{tabular}{|c|c|c|c|c|c|c|c|c|c|c|}
\hline $\begin{array}{l}\text { Paris projects } \\
P\end{array}$ & \multicolumn{3}{|c|}{$\begin{array}{l}\text { Minima, the elementary } \\
\text { biology lab } \\
P_{1}\end{array}$} & \multicolumn{2}{|c|}{$\begin{array}{l}\text { Tactile Micro Landscape } \\
\mathrm{P}_{2}\end{array}$} & \multicolumn{3}{|l|}{$\begin{array}{l}\text { IndiCo } \\
\mathrm{P}_{3}\end{array}$} & \multicolumn{2}{|c|}{$\begin{array}{l}\text { Bio-Clock } \\
\mathrm{P}_{4}\end{array}$} \\
\hline $\begin{array}{l}\text { Designers } \\
\text { Des }\end{array}$ & \multicolumn{2}{|l|}{$\mathrm{P}_{1}$ Des $_{\mathrm{a}}$} & $P_{1}$ Des $_{b}$ & $\mathrm{P}_{2} \operatorname{Des}_{\mathrm{a}}$ & $P_{2}$ Des $_{b}$ & $\mathrm{P}_{3} \mathrm{Des}_{\mathrm{a}}$ & $\mathrm{P}_{3}$ Des $_{b}$ & $\mathrm{P}_{3}$ Des $_{\mathrm{c}}$ & $\mathrm{P}_{4}$ Des $_{\mathrm{a}}$ & $\mathrm{P}_{4}$ Des $_{\mathrm{b}}$ \\
\hline $\begin{array}{l}\text { Biologists } \\
\text { Bio }\end{array}$ & \multicolumn{2}{|l|}{$P_{1}$ Bio } & \begin{tabular}{|l}
$\mathrm{M}_{1}$ \\
(post-doc resercher)
\end{tabular} & $\mathrm{P}_{2}$ Bio & \begin{tabular}{|l}
$\mathrm{M}_{2}$ \\
(post-doc resercher)
\end{tabular} & \multicolumn{2}{|l|}{$\mathrm{P}_{3}$ Bio } & \begin{tabular}{|l}
$\mathrm{M}_{2}$ \\
(post-doc resercher)
\end{tabular} & $\mathrm{P}_{4} \mathrm{Bio}$ & \begin{tabular}{|l}
$\mathrm{M}_{2}$ \\
(post-doc resercher)
\end{tabular} \\
\hline $\begin{array}{l}\text { Tokyo projects } \\
T\end{array}$ & \multicolumn{3}{|l|}{$\begin{array}{l}\text { Aura } \\
T_{1}\end{array}$} & \multicolumn{2}{|c|}{$\begin{array}{l}\text { Chemical Synchronisation } \\
T_{2}\end{array}$} & \multicolumn{3}{|c|}{$\begin{array}{l}\text { BIOrigami } \\
\mathrm{T}_{3}\end{array}$} & & \\
\hline $\begin{array}{l}\text { Designers } \\
\text { Des }\end{array}$ & \multicolumn{3}{|l|}{$T_{1}$ Des } & $\mathrm{T}_{2}$ Des & $\mathrm{T}_{2,3}$ Des & \multicolumn{3}{|l|}{$\mathrm{T}_{2,3}$ Des } & & \\
\hline $\begin{array}{l}\text { Biologists } \\
\text { Bio }\end{array}$ & $\begin{array}{l}\mathrm{T}_{1} \mathrm{Bio}_{\mathrm{a}} \\
\text { (professor) }\end{array}$ & $\mathrm{T}_{1} \mathrm{Bio}_{\mathrm{b}}$ & $\begin{array}{l}\mathrm{T}_{1} \mathrm{Bio}_{\mathrm{c}} \\
\text { (professor) }\end{array}$ & $\begin{array}{l}\mathrm{T}_{2} \mathrm{Bio}_{\mathrm{a}} \\
\text { (professor) }\end{array}$ & $\mathrm{T}_{2,3} \mathrm{Bio}$ & $\begin{array}{l}\mathrm{T}_{3} \mathrm{Bio} \\
\text { (professor) }\end{array}$ & & & & \\
\hline
\end{tabular}

Figure 3. Participants' naming scheme according to their profession (designers and biologists, including mentors), the home institution (Paris, Tokyo) and the project. 